\title{
Analysis of Demand for Beef in Semarang Regency
}

\section{Donny Samudra Adetyobagus}

\author{
Jurusan Ekonomi Pembangunan, Fakultas Ekonomi, Universitas Negeri Semarang
}

Permalink/DOI: https://doi.org/10.15294/efficient.v2i2.30798

Received: December 2018 ; Accepted: March 2019 ; Published: Juny 2019

\begin{abstract}
Semarang Regency is one of the districts that has the highest demand for beef in Central Java. Although the price of beef continues to increase every year, but the demand for beef also continues to increase. The purpose of this study was to find out and analyze the factors that influence the demand for beef in Semarang Regency. The method used in this study is quantitative descriptive research. The variables used in this study were demand for beef, beef prices, population, per capita income, and chicken meat prices. The analytical method used in this study is multiple regression analysis with OLS (Ordinary Least Square) method. The results showed that the variable price of beef has a positive and significant effect with a coefficient of 3.460495. The variable population number has a positive and significant effect with a coefficient of 1.276796. The variable income per capita has a positive and significant effect with a coefficient of o.028931. While the variable price of chicken meat does not have a significant effect on the demand for beef. Based on the results of the above research it can be concluded that the variable price of beef, population and per capita income has a positive and significant effect on the demand for beef in Semarang Regency. While the variable price of chicken does not significantly influence the demand for beef in Semarang Regency.
\end{abstract}

\section{Keywords: Beef, Chicken Meat, Population, Income}

\begin{abstract}
Abstrak
Kabupaten Semarang adalah salah satu kabupaten yang memiliki permintaan daging sapi tertinggi di Jawa Tengah. Meski harga daging sapi terus meningkat setiap tahun, namun permintaan akan daging sapi juga terus meningkat. Tujuan dari penelitian ini adalah untuk mengetahui dan menganalisis faktor-faktor yang mempengaruhi permintaan daging sapi di Kabupaten Semarang. Metode yang digunakan dalam penelitian ini adalah penelitian deskriptif kuantitatif. Variabel yang digunakan dalam penelitian ini adalah permintaan daging sapi, harga daging sapi, populasi, pendapatan per kapita, dan harga daging ayam. Metode analisis yang digunakan dalam penelitian ini adalah analisis regresi berganda dengan metode OLS (Ordinary Least Square). Hasil penelitian menunjukkan bahwa variabel harga daging sapi memiliki pengaruh positif dan signifikan dengan koefisien sebesar 3,460495. Jumlah populasi variabel memiliki pengaruh positif dan signifikan dengan koefisien 1,276796. Variabel pendapatan per kapita memiliki pengaruh positif dan signifikan dengan koefisien o,o28931. Sedangkan variabel harga daging ayam tidak berpengaruh signifikan terhadap permintaan daging sapi. Berdasarkan hasil penelitian di atas dapat disimpulkan bahwa variabel harga daging sapi, populasi dan pendapatan per kapita berpengaruh positif dan signifikan terhadap permintaan daging sapi di Kabupaten Semarang. Sedangkan variabel harga ayam tidak berpengaruh signifikan terhadap permintaan daging sapi di Kabupaten Semarang.
\end{abstract}

\section{Kata Kunci: Daging Sapi, Daging Ayam, Populasi, Pendapatan}

How to Cite: Adetyobagus, D. (2019). Analysis of Demand for Beef in Semarang Regency. EFFICIENT Indonesian Journal of Development Economics, 2(2), 395-403. https://doi.org/10.15294/efficient.v2i2.30798

(C)2019 Semarang State University. All rights reserved

\footnotetext{
Alamat Korespondensi :

Alamat: Gedung L2 Lantai 2 FE Unnes

Kampus Sekaran, Gunungpati, Semarang, 50229

E-mail : efficientjournal@gmail.com
}

ISSN 2655-6197 


\section{INTRODUCTION}

The development of livestock subsector business is one part that is related to agricultural development. Agricultural development is directed at realizing a resilient, advanced and efficient agriculture that can be characterized by its ability to improve the welfare of farmers and can encourage economic growth in the region as a whole. The agricultural sector has several sub-sectors, namely the food crop sub-sector, the plantation subsector, the livestock sub-sector, the forestry sub-sector and the fisheries subsector. Field of animal husbandry. One of the livestock business that is developed by many people in rural areas is beef cattle farming. One of the provinces in Indonesia that has the potential of beef cattle breeding is Central Java Province. Many beef cattle farms have been developed in Central Java Province because of the geographical area of Central Java which is dominated by mountainous areas, so the availability of animal feed is very abundant. Data on beef cattle population and beef cattle production in Central Java are presented in Figure 1 as follows :

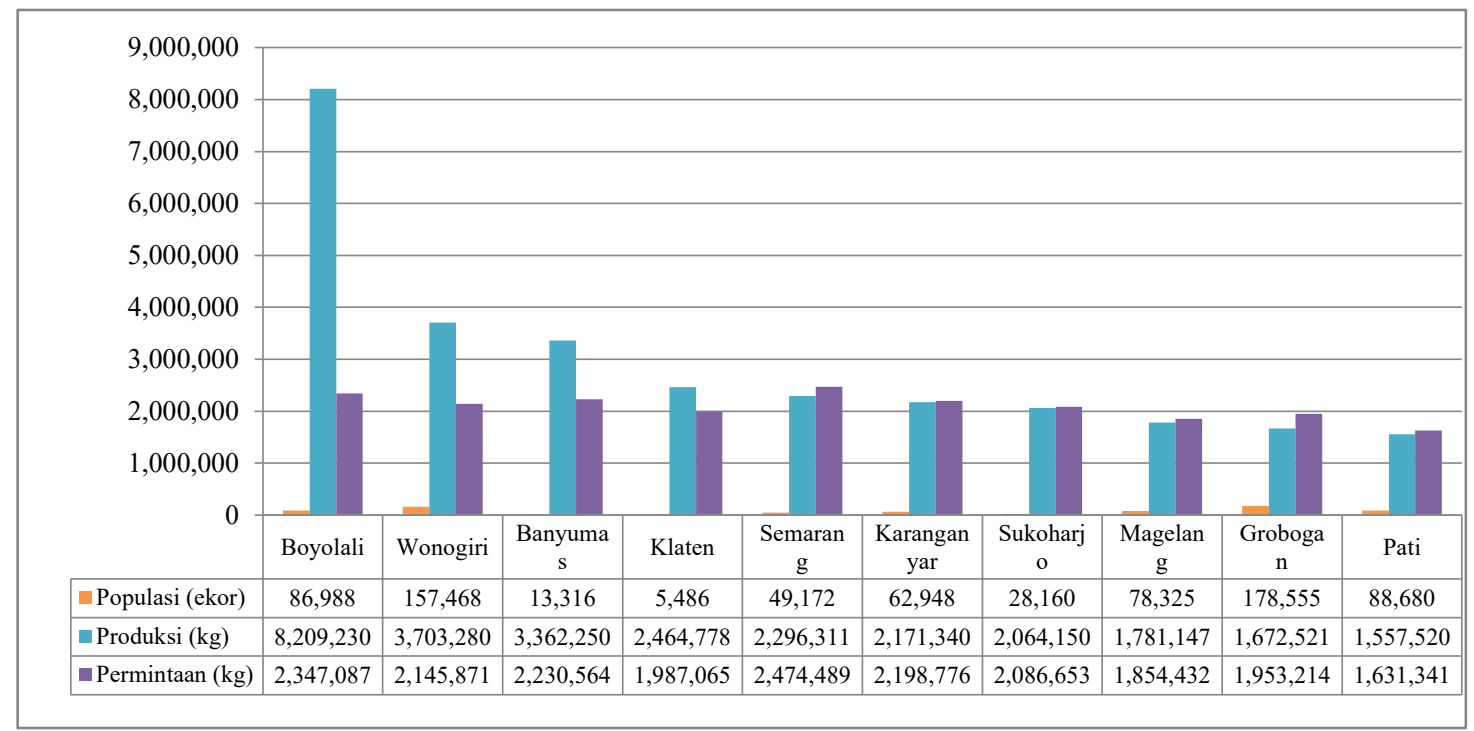

Figure 1. Number of Beef Cattle Population and Beef Meat Production Number per largest Regency in Central Java Province in 2015

Source: Central Java Province BPS 2016

Based on Figure 1 above shows that the districts in Central Java which have the highest beef cattle population in 2015 were Grobogan Regency which was as much as 178,555 tails. Then followed by Wonogiri Regency in the sequence with a population of 157,468 . Furthermore, the district that has the highest amount of cattle production is Boyolali Regency with a production of 8,209,230 kg. Followed by
Wonogiri Regency in the second place with a total production of 3,703,28o kg. Whereas when viewed from the request, the demand for the most beef is Semarang Regency, which is $2,474,489 \mathrm{~kg}$. When viewed from the population and number of beef cattle production, the Semarang district is still inferior to other districts. However, when viewed from the demand for beef, the demand for beef in Semarang 
Regency ranks first compared to other districts.

Demand for beef in Semarang Regency during the period of 2012 to 2016 tends to increase. In 2012, the demand for beef in Semarang Regency was 1,720,730 $\mathrm{kg}$. Then in 2013 it increased to $2,296,311 \mathrm{~kg}$ and continued to increase until 2016 to reach 2,846,579 kg (BPS, 2017). Priyanti (2015) said that the demand for beef is influenced by various factors including beef prices, substitute meat prices, people's income and population. The price of beef will greatly influence the demand for beef. Likewise with the price of substitute meat such as chicken meat also affects the demand for beef. In the study of mujiyanto (2001) it was said that the price of beef had a negative effect on the demand for beef. When the price of beef itself rises, the amount of beef requested will go down. In accordance with the demand theory that if the price of an item rises, the number of items requested will decrease.

The price of beef in Semarang Regency during the 2012-2016 period continues to increase. The price of beef in 2012 was Rp. 90,333. Then in 2013 it increased to Rp. 91,913, which continued to increase until 2016, reaching Rp. 106,672 (BPS, 2017). However, the increase in beef does not cause beef to decline but instead the demand for beef is increasing. This is certainly not in accordance with the request theory which states that the increase in the price of an item will cause the demand for goods to decline. This study aims to find out and analyze the factors that influence the demand for beef in Semarang Regency.

\section{METHOD}

In this study, the research method used is quantitative research methods. The population in this study was beef prices, population, per capita income, price of chicken meat in Semarang Regency for 5 years, namely in 2012-2016. The samples used were beef prices, population, per capita income, price of chicken meat at the end of the month data with a 5-year observation period namely 2012-2016 so that a sample of 60 samples was obtained. The data in this study were obtained secondary. Secondary data in this study are data obtained through official agencies, such as the Office of Agriculture, Fisheries and Food of Semarang Regency, and Semarang Regency Central Bureau of Statistics and data that are officially published books, journals, and reports related to this research.

In this study using 4 independent variables, namely beef prices, population, income, price of substitute goods. The dependent variable is demand for beef in Semarang Regency. The analytical method used in this research is descriptive method and quantitative method to analyze the factors that influence the demand for beef, descriptive method is used to see the development of demand for beef in Semarang Regency. While the quantitative method with multiple linear regression equations is used to analyze the factors that influence the demand for beef. with OLS (Ordinary Least Square) method. The Multiple Linear Regression Model in this study are as follows:

$Y=a+\beta_{1} X_{1}+\beta_{2} X_{2}+\beta_{3} X_{3}+\beta_{4} X_{4}+e$ 
Information:

$\mathrm{Y}=$ Demand for Beef

$\mathrm{a}=$ Constant

$\mathrm{X}_{1}=$ Beef Prices

$\mathrm{X}_{2}=$ Population

$\mathrm{X}_{3}=$ Per capita income

$\mathrm{X}_{4}=$ Price of Chicken Meat (Price of Goods Substitution)

$\mathrm{e}=$ error

\section{RESULTS AND DISCUSSION}

The results of multiple linear regression calculations regarding the analysis of demand for beef in Semarang Regency, there are several factors that influence the demand for beef, namely beef prices, chicken meat prices, population and per capita income. The results of the calculation are as follows:

Table 1. Results of Multiple Linear Regression Estimates

\begin{tabular}{lllll}
\hline Variabel & Koefisien & Std. Error & t-Statistik & Prob \\
\hline Konstanta (c) & -12.56659 & 5820816. & -2.502499 & 0.0112 \\
Harga Daging Sapi & 3.460495 & 1.565948 & 3.937228 & 0.0008 \\
Jumlah Penduduk & 1.276796 & 8.764588 & 0.290687 & 0.046 \\
Pendapatan Perkapita & 0.028931 & 0.099526 & 0.290687 & 0.0472 \\
Harga Daging Ayam & - & & & \\
n $=60$ & 2.609587 & 3.875922 & -1.189288 & 0.1994 \\
R-squered = o.977938 & & & & \\
Adjusted R-squered = 0.976334 & & & & \\
F-statistik = 6o.94970 & & & & \\
F(Sig)= o,ooo & & & & \\
\hline Source: Da procssed & & & & \\
\end{tabular}

Source: Data processed eviews 9, 2018

Based on table 1. the results of the analysis of demand for beef in Semarang Regency after the calculation is done, the following multiple linear regression equation models are obtained:

$$
\begin{aligned}
Y= & -12,56659+3,460495 \text { price of beef } \\
& +1.276796 \text { total population }+ \\
& 0.028931 \text { per capita income - } \\
& 2.609587 \text { price of chicken meat }
\end{aligned}
$$

From the equation model, it was found that the regression coefficient of the variable price of beef, population, income per capita was positive, while the variable price of chicken meat was negative. In this case the variable price of beef is the variable that has the most dominant influence on the demand for beef in Semarang Regency which is indicated by the standardized coefficient value greater than other variables with a standardized coefficient value of 3.460495 .

Based on the multiple linear regression equation above, it can be interpreted as follows: The dependent variable is a variable whose value will be predicted by the independent variable. In this study the dependent variable (Y) is demand for beef in Semarang Regency whose value will be predicted by the variable price of beef, 
population, income per capita, price of chicken meat.

The constant shows a value of 12.56659. This means that when the independent variable price of beef, population, income per capita, and the price of chicken meat are considered constant or have a value of $o$, then the demand for beef will decrease by 12.56659 .

The coefficient of regression of beef prices with a value of 3.460495 . This means that when the price of beef has increased by 1 rupiah, the demand for beef in Semarang Regency will increase by 3.460495 assuming other variables are considered constant or have a value equal to $o$. The coefficient of the variable price of beef is positively meaning that there is a positive relationship between prices beef with beef demand.

The regression coefficient of the population is valued at 1.276796 . This means that when the population increases by 1 soul, the demand for beef in Semarang Regency will increase by 1.276796 assuming other variables are considered constant or have a value equal to o. The variable coefficient of the population is worth positive means that there is a positive relationship between the population and the demand for beef.

The regression coefficient of per capita income is 0.028931. This means that when per capita income increases by 1 rupiah, the demand for beef in Semarang Regency will increase by 0.028931 assuming other variables are considered constant or have a value equal to o. The per capita income coefficient is positive, meaning there is a positive relationship between per capita income and demand beef.

The coefficient of regression for the price of chicken is worth -2.609587 . This means that when the price of chicken meat increases by 1 rupiah, the demand for beef in Semarang Regency will decrease by 2.609587. assuming other variables are considered constant or have a value equal to $o$. The coefficient of chicken meat prices is negative, meaning that there is a negative relationship between the price of chicken meat and the demand for beef.

The results showed that the variable price of beef had a positive and significant effect on the demand for beef in Semarang Regency. The regression coefficient of beef price variable is 3,460495 , meaning that with the increase in beef prices of 1 rupiah, the demand for beef will increase by 3,460495 assuming other variables are considered constant. According to the hypothesis test the age variable t-statistic is $3.937228<\mathrm{t}$-table 1,675 , then $\mathrm{Ho}$ is rejected and $\mathrm{H}_{1}$ is accepted. This shows that the variable price of beef has a positive and significant effect on the demand for beef in Semarang Regency. The estimation results of this study are not in accordance with the hypothesis that the price of beef has a negative and significant effect on the demand for beef in Semarang Regency. Price is one of the most important elements in determining market share and profitability. Generally the most price-sensitive customers for high-value or frequently purchased products. They are less sensitive to prices for low-value goods or items that are rarely bought (Kottler, 200o). Livestock products generally have relatively high prices compared to other 
agricultural commodities. Demand for livestock products is closely related to the purchasing power of consumers. The increasing income of the community causes the demand for high quality products to increase. Along with the increase in people's income, it causes an increase in purchases of goods or products that are better (Rasyaf, 200o). The price of beef in Semarang Regency has annual fluctuations when approaching major holidays such as the new year or high holiday prices are high even the highest prices have reached Rp. 115,632, soaring prices of beef did not cause public demand to decline, but on the contrary the demand for beef actually increased. This is not in accordance with the demand theory which says that when the price of an item rises, the number of items requested will go down.

The results of this study are not in accordance with Munarka's study (2015) which states that the price of beef does not significantly influence the demand for beef in Palopo City. The results of this study are also not in accordance with the research of Mujiyanto (2001) which states that the price of beef has a negative effect on the demand for beef. Demand for beef that is not in accordance with the theory in Semarang Regency is caused by people's need for beef which is very high and cannot be replaced with other meat. For example in industries that use the main staple of beef such as the meatball, sausage industry and various other industries. The industry must continue to produce even though the price of beef rises, so that when the price of beef rises the amount of beef demanded remains high.
The results showed that the population variable had a positive and significant effect on the demand for beef in Semarang Regency. The variable regression coefficient of population is 1.276796 , with an increase in population of 1 soul, the demand for beef is also increased by 1.276796 , assuming other variables are considered constant. According to the hypothesis test variable number of population t-Statistics $1.799053>\mathrm{t}$ table 1.675, then Ho is rejected and $\mathrm{H}_{2}$ is accepted. This shows that the variable population has a positive and significant effect on the demand for beef in Semarang Regency.

The results of this study are not in accordance with Putri's research (2013) which states that the population does not significantly influence the demand for beef in Medan City. The results of this study are also not in accordance with the haromain research which states that the population actually has a negative effect on the demand for beef in Indonesia. However, the results of this study are consistent with the research of Mujiyanto (2001) which states that the population has a positive effect on the demand for beef in Manokwari. Population increase does not necessarily lead to increased demand. However, usually population increases are followed by developments in employment opportunities. Thus more people receive income and this will increase purchasing power in the community to shop. This increase in purchasing power will increase demand. Residents are all people domiciled in the geographical area of the Republic of Indonesia for six months or more and / or those who live less than six months but aim to settle. (Johny Purba 
2012) says residents are people whose spells are personal, family members, community members, citizens and a set of quantities that reside somewhere within the country's borders at a certain time. (Kartomo, 2012) says the population is all people who inhabit a certain area at a certain time, regardless of citizens or noncitizens. (Simanjuntak, 2012) says residents are those who reside or domicile within a country.

Increasing population will actually create / increase overall demand, especially for investment. The population increase is not just an addition to the population but also as an increase in purchasing power. Therefore, if there is a decrease in the number of residents, it will cause a decrease in stimulus to make an investment so that the demand will also decrease. If population development is delayed, it will have an estimate that the market will be narrower. But on the contrary, if the population is not qualified, the rapid development of the population will actually hamper economic development. Therefore a high population growth demands continuous economic development. Based on the study of the theory that has been studied in terms of population, its measurement uses the soul.

The results showed that the variable income per capita had a positive and significant effect on the demand for beef in Semarang Regency. The regression coefficient of variable income per capita is 0.028931, with an increase in per capita income of 1 rupiah, the demand for beef is also increased by 0.028931 assuming other variables are considered constant. According to the hypothesis test the variable income per statistic per capita 2,290687> t-table 1,675, then Ho is rejected and $\mathrm{H}_{3}$ is accepted. This shows that the variable income per capita has a positive and significant effect on the demand for beef in Semarang Regency.

The results of this study are not in accordance with Putri's research (2013) which states that per capita income does not significantly influence the demand for beef in Medan City. However, the results of this study are in line with Munarka's study (2015) which states that per capita income has a positive and significant effect on the demand for beef in Palopo City. This research is also in accordance with Fatmawati's study (2016) which states that per capita income has a positive and significant effect on the demand for beef in Indonesia.

Community income is income from salaries or remuneration from results obtained by individuals or kelompiok households in one month and used to meet daily needs. While income from the side business is additional income which is another income from outside the main activity or work done by someone. The side income that is obtained directly can be used as a support or increase in basic income. Soekarwati (2002) explains that income will affect the amount of goods consumed, that often found with increasing income, the goods consumed not only increase, but also the quality of the goods is also a concern. For example, before the addition of rice income, it is assumed that the quality is not good, but after an increase in income, the rice consumed becomes better quality.

The results showed that the variable price of chicken meat did not have a positive and significant effect on the demand for beef in Semarang Regency. The regression coefficient of the variable 
price of chicken meat is 2.609587 , with the increase in the price of chicken 1 rupiah, the demand for beef is also increasing by 2.609587 assuming other variables are considered constant. According to the hypothesis test the variable price of chicken meat t-Statistics -1,189288<t-table 1,675, then $\mathrm{Ho}$ is accepted and $\mathrm{H}_{4}$ is rejected. This shows that the variable price of chicken meat has a negative and not significant effect on the demand for beef in Semarang Regency.

The results of this study are in accordance with Putri's research (2013) which states that the price of chicken meat does not significantly influence the demand for beef in Medan City. But the results of this study are not in accordance with Munarka's study (2015) which states that the price of chicken has a positive and significant effect on the demand for beef in Palopo City. The reason for the incompatibility of the results of this study with the theory is that beef in Semarang Regency is a source of certain raw materials so that it cannot be replaced by chicken meat. Therefore, when the price of chicken meat increases, the increase will not affect the demand for beef in Semarang Regency.

The results showed that the value of F-statistic was 60.94970> F-table 5.05, then Ho was rejected and $\mathrm{H} 1$ was accepted. This shows that the variable price of beef, population, income per capita, the price of chicken meat together have a positive and significant effect on the demand for beef in Semarang Regency. The results of these studies are in accordance with the hypothesis in this study.

The results of this study are not in accordance with Putri's research (2013) which states that beef prices, prices of substitute goods, prices of complementary goods and GDP per capita together do not have a significant effect on demand for beef in Medan City. However, the results of the study are consistent with Munarka's (2015) study which states that beef prices, chicken meat prices, income, number of family members and tastes together have a significant effect on the demand for beef in Palopo City. The results of this study are also in line with the research of Haryati (2017) which states that the demand for beef in D.I Yogyakarta is jointly influenced by the price of beef, chicken meat prices, goat meat prices, rice prices, egg prices, population, and income.

\section{CONCLUSION}

Based on the results of the research on the analysis of demand for beef in Semarang Regency described above, it can be concluded that the price of beef has a positive and significant effect on the demand for beef in Semarang Regency in 2012-2016. The population has a positive and significant effect on the demand for beef in Semarang Regency in 2012-2016. Per capita income has a positive and significant effect on the demand for beef in Semarang Regency in 2012-2016. The price of chicken meat has a negative and not significant effect on the demand for beef in Semarang Regency in 2012-2016. The price of beef, population, and income per capita together have a significant effect on the demand for beef in Semarang Regency in 2012-2016.

Based on the conclusions that have been explained, the suggestion that can be given is that the government as the policy holder and price controller must always pay attention to the price and supply of beef, given that beef is a basic need for the 
community as well as industrial raw materials. The availability of beef on the market must always be kept in mind, given the increasing number of people requiring higher availability of beef. High and low beef must always be accessible to the community, especially those with low income. The high and low demand for beef is influenced by beef prices, population, per capita income and price of chicken meat. From all these factors, stability must be maintained so that the people and industries made from beef are still able to obtain beef at affordable prices and availability.

\section{REFERENCES}

Badan Pusat Statistik, 2017. Badan Pusat Statistik Kabupaten Semarang Dalam Angka. [Online] Available at: semarangkab.bps.go.id [Accessed 20 desember 2018].

Dinas Pertanian, Pangan dan Perikanan Kabupaten Semarang, 2018. Data Harga Daging Sapi di Kabupaten Semarang 2016. Disper Kabupaten Semarang.
Dinas Pertanian, Pangan dan Perikanan Kabupaten Semarang, 2018. Data Jumlah Permintaan Daging Sapi di Kabupaten Semarang 2016. Disper Kabupaten Semarang.

Priyanti, Atien, 2015. Estimasi Sistem Permintaan dan Penawaran Daging Sapi di Provinsi Lampung. Balai Penelitian Ternak. Bogor: Indonesia

Mujiyanto. 2001. Analisis Permintaan Daging Sapi di Kota MAnokwari. Skripsi. Universitas Cenderawasih Manokwari.

Kotler, Philip., 2007. Dasar-Dasar Pemasaran. Jakarta: Indeks.

Rasyaf, Muhammad., 20oo. Memasarkan Hasil Peternakan. Jakarta: Swadaya.

Munarka, Hasbi, dkk. 2015. Faktor-Faktor Yang Mempengaruhi Permintaan Dagang Sapi Potong Di Kota Polopo. Jurnal Ekonomi Pembangunan. Voll 2(1).

Fatmawati, Jamal, 2016. Faktor-faktor yang Mempegaruhi Permintaan Daging Sapi di Indonesia. Jurnal Ekonomi. Universitas Halu Oleo.

Haryati, Annisa. 2017. Faktor-Faktor Yang Mempengaruhi Permintaan Daging Sapi Di Daerah Istimewa Yogyakarta. Skripsi. Universitas Muhammadiyah Yogyakarta. 